\section{Environment changes at the Ludlow and Pridoli boundary (Subpolar Urals)} Engineering, University of Miskolc - slava.kanev.1995@mail.ru

TatIANA M. BEZNOSOVA - Institute of Geology Komi SC UB RAS, Syktyvkar - beznosova@geo.komisc.ru VLADIMIR A. MATVEEV - Institute of Geology Komi SC UB RAS, Syktyvkar " vamatveev@geo.komisc.ru LÁsZló A. GÖMZE - Dept. Of Ceramics and Silicate Engineering at Institute of Ceramics and Polymer Engineering, University of Miskolc= femgomze@uni-miskolc.hu

Érkezett: 2017. 11. 04. " Received: 04. 11. 2017. " https://doi.org/10.14382/epitoanyag-jsbcm.2017.24

\section{Abstract}

The section of the Upper Silurian on the Western slope of the Subpolar Urals is located on the Kozhym River bank. This paper presents the results of studying of the geological structure of the upper Ludlowian section and data on lithology, geochemistry, and environment reconstructions of carbonate-terrigenous deposits of the late Ludlow and at the boundary of the Ludlow and Pridoli.

Keywords: environment, isotopes of carbonate carbon and oxygen, Ludlow, Pridoli, Sr/Ba ratio, Upper Silurian, Urals

Kulcsszavak: környezet, szén és oxigén izotópok, Ludlowi, Pridoli, Sr/Ba arány, késô Szilur
Bronislav I. KANEV - Dept. Of Ceramics and Silicate Engineering at Institute of Ceramics and Polymer

Bronislav I. KANEV

Graduated master's courses at the Syktyvkar State University named after P. Sorokin in the specialty Geology. In the process of studying in the magistracy the main fields of scientific interests were focused on conditions of formation of Upper Silurian deposits and association of Late Silurian benthic fauna on the Western slope of the Subpolar Urals. At present he is a PhD student at University of Miskolc under supervision of Prof. L. A. Gömze.

Tatiana M. BEZNOSOVA

Works at the N.P. Yushkin Institute of Geology, Komi Science Centre, Ural Division, Russian Academy of Sciences, Syktykar (Russian Federation). Author of 4 books and more than 150 articles.

Vladimir A. MATVEEV Scientific employee in the laboratory of stratigraphy at the N.P. Yushkin Institute of Geology of the Komi SC UB RAS. Main fields of his research interest are stromatolite constructions of the Silurian of the Western slope of the Urals and the Chernov uplift $\mathrm{He}$ is author of more than 30 scientific papers.

László A. GÖMZE

Establisher (in July 1st, 1999) of the Department of Ceramics and Silicate Engineering in the University of Miskolc, Hungary. Since then 7 students from the department have successfully completed their PhD theses and 4 of them were managed by Prof. Gömze. He is author or coauthor of 2 patents, 5 books and more than 250 scientific papers. Recently, he is the chair of the International Organization Board of ic-cmtp5 the 5th International Conference on Competitive Materials and Technological Processes (2018) and ic-rmm3 the 3rd Internationa Conference on Rheology and Modeling of Materials (2017).

\section{Introduction}

In the regional stratigraphic scheme of the Urals adopted in 1991 the upper Ludlow on the investigated territory corresponds to the Sizim Regional Stage (= Ludfordian). The Lower Pridoli corresponds to the Belush'ya Regional Stage. The boundary of the Ludlow and Pridoli is established in the roof of the terrigenous-carbonate sequence $[1,2]$. At the same time, there is another approach to determining the boundary between Ludlow and Pridioli [3].

This work is aimed to characterizing of the environment reconstruction of the boundary beds of the Sizim Regional Stage of Ludlow and Belush ya Regional Stage of Pridoli.

The section of the boundary deposits of the Ludlow and Pridoli (section 236) is located on the left bank of the Kozhym River, in 700 m below the mouth of the Syv' yu River (Fig. 1).

\section{Materials and methods}

More than 80 samples of carbonate rocks have been studied to reconstruct the sedimentation environment of the Ludlow and Pridoli boundary deposits. Stratified sampling was conducted from all types of deposits transversely to stretch of rocks, every $50 \mathrm{~cm}$. The barium and strontium contents were determined by the emission spectral analysis. Measurements of the stable isotopes ratios of carbon and oxygen $\left(\delta^{13} \mathrm{C}\right.$ and $\left.\delta^{18} \mathrm{O}\right)$ are made with mass spectrometer «DELTA V Advantage». All analytical works were carried out at the N.P. Yushkin Institute of Geology of the Komi Scientific Centre of Ural Branch of Russian Academy of Sciences (in further: SC UB RAS).

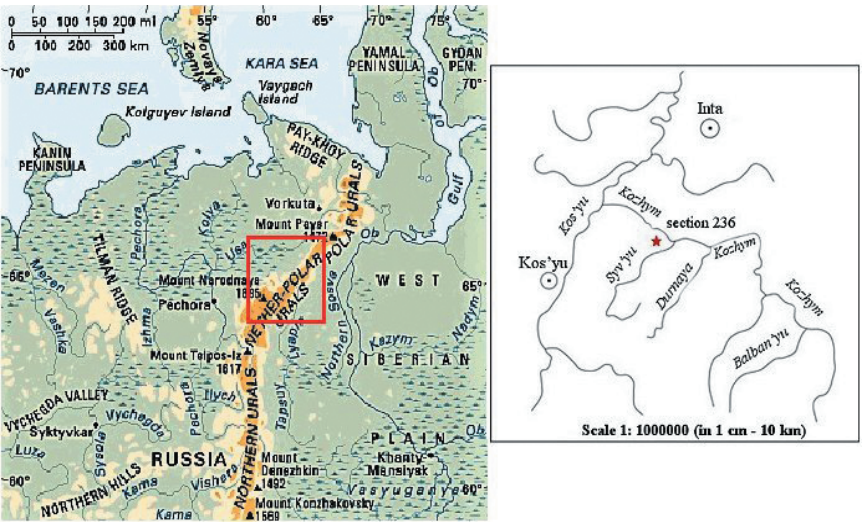

Fig.1. Scheme of the location of the studied section in the Kozhym river basin(latitude N65\%40'0.86", longitude E59 $45^{\circ} 2.09^{\prime \prime}$ ).

1. ábra A vizsgált szakasz helye a Kozhim-medencében (N65 40 ’0.86 “szélesség, E59 45'2.09” hosszúság)

\section{Results and discussion}

By the ratio $\mathrm{Sr} / \mathrm{Ba}$ in sediments of the same age is possible to trace the transition from less saltwater sediments to normal marine, the Sr / Ba ratio of more than one indicates marine conditions, a ratio of less than one indicates a saltwater water environment. The increase in this ratio indicates an increase in salinity, and, conversely, it's lowering - the decrease in salinity $[4,5]$.

The distribution of the $\mathrm{Sr} / \mathrm{Ba}$ ratio in the Upper Ludlow sediments is uneven with numerous deviations in the direction of increase and decrease, and varies from 0,57 to 30 . The $\mathrm{Sr} /$ Ba ratio in the Lower Pridoli deposits varies from 1 to 7,9 (Fig. 
2). Bearing in mind that most of the samples came from the boundary deposits of Ludlow and Pridioli showed a $\mathrm{Sr} / \mathrm{Ba}$ ratio greater than one, it can be concluded that normal marine environment were in palaeobasin at the boundary of Ludlow and Pridoli.

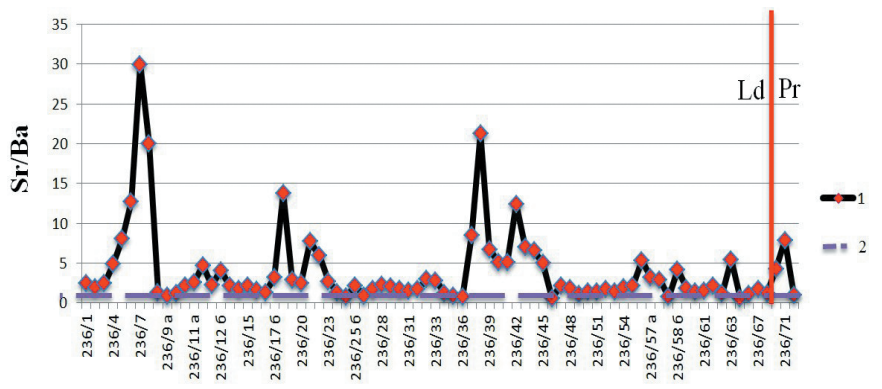

Fig. 2. Distribution of $\mathrm{Sr}$-Ba values in the studied interval of the Ludlow and Pridoli sections - (1); the boundary between normal-marine and desalinated environments - (2).

2. ábra Az Sr-Ba értékek eloszlása a Ludlow és Pridoli szakaszok tanulmányozott intervallumában - (1); a normál tengeri és a sótalan környezet közötti

határvonal - (2)
The concentration of strontium in the samples of the Upper Ludlow varies from 46 to $450 \mathrm{ppm}$ is shown in Fig. 3. We must underline that the fault of this method can be obtained up to $27,7-30 \%$. The Clarke' concentration of strontium in carbonate rocks by A.A. Beus is 610 ppm [6]. The study samples demonstrate lower Sr concentration. This is probably due to the fact that these carbonate deposits formed under conditions of hydrodynamic activity of water, at which strontium could be released $[7,8]$. Such values indicate the penetration of freshwater in the basin [9].

The results of isotopic analysis of the boundary deposits of Ludlow and Pridoli are shown in graphs (Figs. 3 and 4). These results showed that none of the figurative points of distribution of $\delta^{13} \mathrm{C}$ and $\delta^{18} \mathrm{O}$ in the carbonate rocks of the Ludlow and Pridoli deposits did not fall within the range of the isotopic composition characteristic of the carbonate of normal sedimentary origin (Fig. 4). This probably indicates specific environment of sedimentation of these carbonate rocks.

The isotopic composition of carbon in the studied carbonate deposits of the upper Ludlow is characterized by a change in

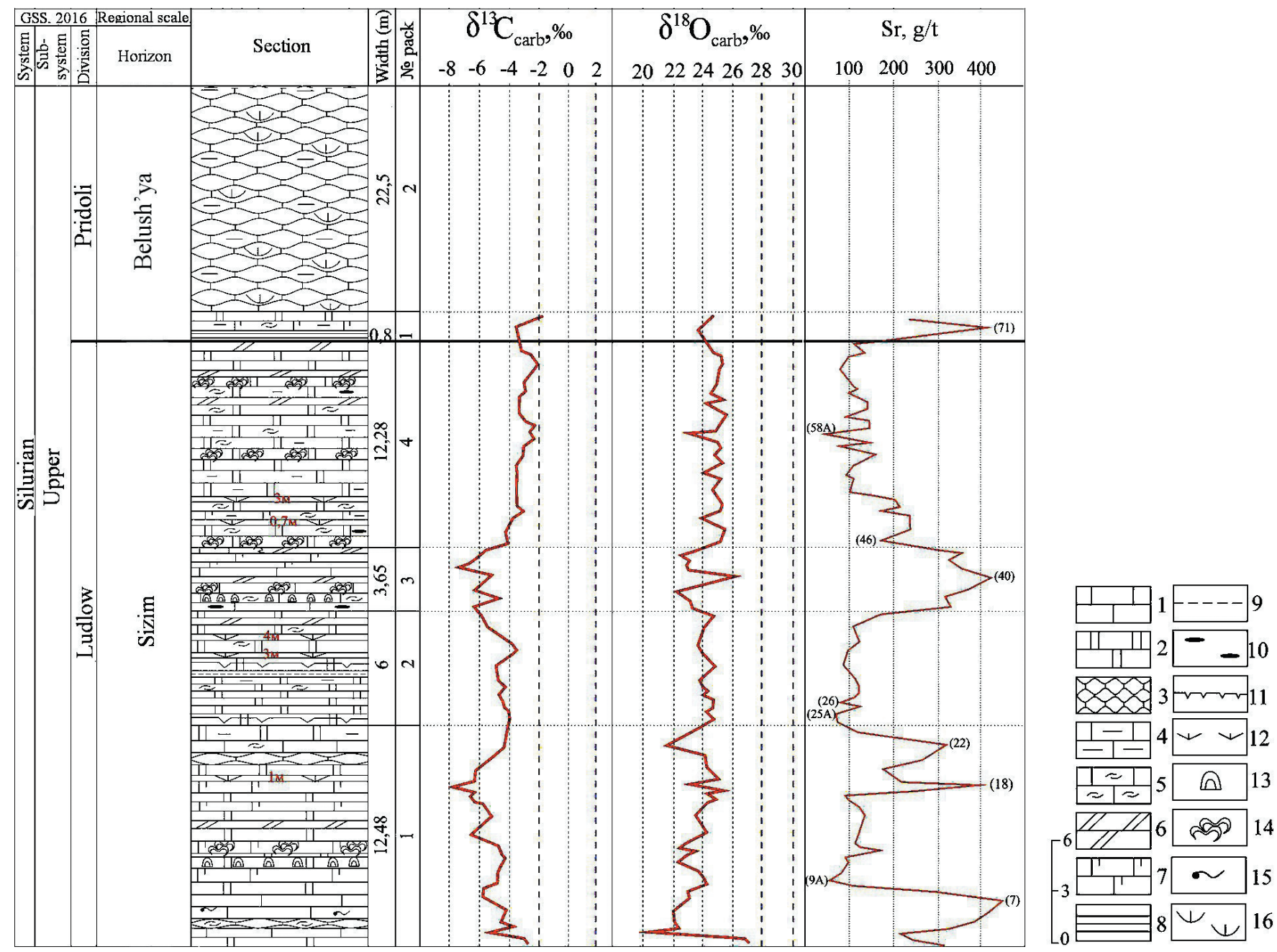

Fig. 3. The distribution of strontium, isotopes of carbonate carbon and oxygen in the boundary deposits of Ludlow and Pridoli on the Western slope of the Subpolar Urals (section 236). Legend: 1 - limestone; 2 - dolomite; 3 - limestone cloddy; 4 -limestone clayey; 5 - limestone detritus; 6 - marl; 7 - dolomitic limestone; 8 - argillite; 9 - clay; 10 pebble; 11 - mud cracks; 12 - covered interval; 13 - stromatoporoids; 14 -stromatolites; 15 - burrows; 16 - brachiopod coquina.

3. ábra A stroncium, a karbonát-szén és az oxigén izotópjai az Urál-hegység szubpoláris nyugati lejtőjén a Ludlow és a Pridoli határövezetben (236. szakasz). Jelmagyarázat: 1 mészkő; 2 - dolomit; 3 - rögös mészkő; 4 - agyagos mészkő; 5 - törmelékes mészkő; 6 - márga; 7 - dolomitikus mészkő;

8 - agyagpala; 9 - agyag; 10 - kavics; 11 - sár repedések; 12 - fedett intervallum; 13 -stromatolit poroidok; 14 - stromatolitok; 15 - zárványok; 16 - spirális coquina. 
the value of $\delta^{13} \mathrm{C}$ from $-2,8 \%$ at the beginning, $-7,8 \%$ closer to the middle part, then there is an increase in the values of $\delta^{13} \mathrm{C}$ to $-3,2 \%$ in the upper part of the studied section. At the same time, the value of $\delta^{18} \mathrm{O}$ has a tendency to decrease from 27,1 to $20,4 \%$ in the lower part of the section, then there is a tendency to increase to $26,1 \%$ in the middle part. The upper part of the sequence demonstrates absence of significant changes in $\delta^{18} \mathrm{O}$.

The isotopic composition of carbon and oxygen in the deposits of the Lower Pridoli are characterized by an increase in the values of $\delta^{13} \mathrm{C}$ (from 3,6 to $1,7 \%$ ) and $\delta^{18} \mathrm{O}$ (from 23,6 to $24,6 \%$ ).

In general, the boundary deposits of the Ludlow and Pridoli are characterized by lower values of $\delta^{13} \mathrm{C}$ (from $-2,1$ to-7,8\%) compared with conventional marine carbonates (from -2 to $2 \%$ ) (Fig. 3). This probably indicates a sufficiently high bioproductivity in the basin [10].

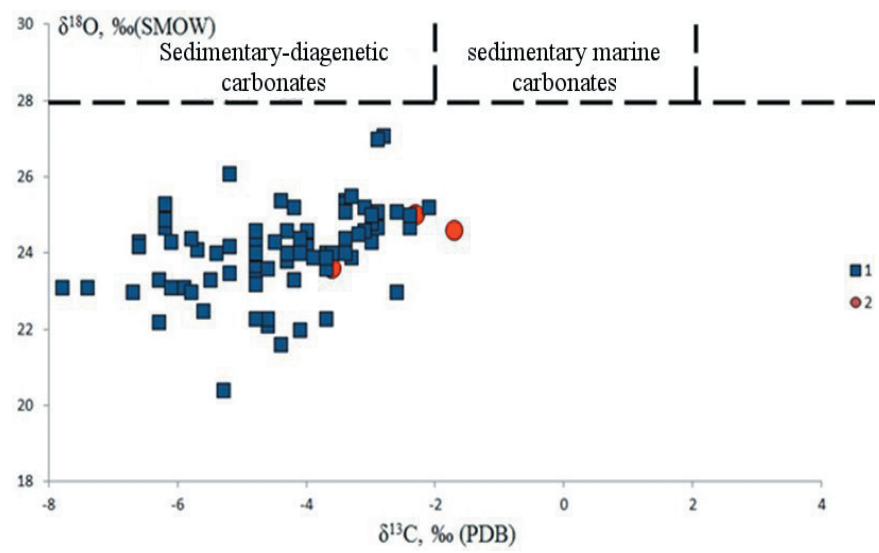

Fig. 4. Distribution of $\delta^{13} \mathrm{C}$ and $\delta^{18} \mathrm{O}$ in carbonate rocks of the Upper Ludlow and Lower Pridoli deposits: 1 - Ludlow deposits; 2 - Pridoli deposits.

4. ábra A $813 \mathrm{C}$ és $\delta 180$ eloszlása a felső Ludlow és az alsó Pridoli karbonátos kőzetekben: 1 - Felsö Ludlow; 2 - Alsó Pridoli

The isotopic composition of oxygen in the carbonate deposits of the upper Ludlow also has lower values of $\delta^{18} \mathrm{O}(20,4-27,1 \%)$ compared with conventional marine carbonates $(28-30 \%$ ) (Figs. 3 and 4). This may be a consequence of the influence of two factors: insignificant desalination and higher temperatures of paleobasin water. The fluctuation of the temperature gradient can be associated with the water circulation, and the change in the salinity of the water with the influx of fresh meteoric waters [8]. At the turn of the Ludlow and Pridoli there is a cardinal change in the composition of biota $[11,12]$.

\section{Conclusion}

Sedimentation in Ludlow occurred in a fairly bioproductive basin with a relative low sea level, slightly desalinated and with relatively high water temperatures.

Boundary deposits of the Ludlow and Pridoli were formed in environment of increased hydrodynamics with periodic influx of fresh water into the basin. Shallowing of the basin in the late Ludlow followed by transgression in the early Pridoli caused biotic turnover in the North Urals palaeobasin. The basin occupied the north-eastern margin of the Baltia palaeocontinent.

\section{Acknowledgement}

This work was supported by the Program of Fundamental Research of RAS "Biota in the geological history of the TimanSeverouralsk region: phylogenetics, evolution, paleecology and paleoclimate, biostratigraphy, stratigraphic geocorrelation" (project no. 115012130017).

\section{References}

[1] Matveev, V. A. - Kanev, B. I. (2016): Features of the upper Ludlow deposits in the silurian key section on the western slope of the Subpolar Urals. Vestnik of Institute of Geology Komi SC UB RAS. 2016. № 8 (260). pp. 3-8.

[2] Explanatory notes to the stratigraphical schemes of the Urals: Precambrian, Paleozoic. Antsygin N. Ya., Ed., Yekaterinburg, 1994.

[3] Modzalevskaya, T. L. - Märss, T. (1991): On the age of the lower boundary of the Greben Regional Stage of the Urals. Proceedings of the Estonian Academy of Sciences. Geology, 1991. 40 (3), pp. 100-103.

[4] Katchenkov, S. M. (1959): Small chemical elements in sedimentary rocks and oils. - Leningrad: Gostoptekhizdat, 1959. - (Tr. VNIGRI, issue 143). $271 \mathrm{p}$.

[5] Maslov, A. V. (2005): Sedimentary rocks: Methods of study and interpretation of obtained data: Textbook / Maslov A. V. Ekaterinburg: Publishing house of the USMU, 2005. - $289 \mathrm{p}$.

[6] Perelman A. I. (1989): Geochemistry. Moscow: Higher School, 1989. - 528 p.

[7] Letnikova, E. F. (2005): Geochemical specificity of carbonate deposits of various geodynamic settings of the northeastern segment of the PaleoAsiatic Ocean. Litosfera = Lithosphere, 2005. - No. 1. pp. 70-81.

[8] Yudovich, Ya. E. (1981): Regional geochemistry of sedimentary strata. Leningrad, Nauka, 1981, $276 \mathrm{p}$.

[9] Yudovich, Ya. E. - Ketris, M. P. (2011): Geochemical indicators of lithogenesis (lithological geochemistry). Syktyvkar: Geoprint. 2011. 742 p.

[10] Nurgalieva, N. G. (2005): Relationship between carbon and oxygen isotopes in carbonate rocks in the eastern Russian Plate. Uchen. Zap. KGU. Estestven. Nauki, 2005, vol. 147. part 3. pp. 38-48.

[11] Beznosova, T. M. (2008): Brachiopod communities and biostratigraphy of Upper Ordovician, Silurian and Lower Devonian of the north-eastern margin of Baltica Palaeocontinent. Ekaterinburg. UrO RAN, 2008. 218 p.

[12] Beznosova, T. M. - Matveev, V. A. - Sokolova, L. V. - Kanev B. I. (2017): Regional manifestation of the global Ludford event (Lau Event) in the section of the Western slope of the Subpolar Urals. Geodynamics, substance, ore genesis of the East European Platform and its folded framing: Extended abstract of scientific conference reports. Syktyvkar: IG Komi SC UB RAS, 2017. pp. 19-21.

$\underline{\text { Ref.: }}$

Kanev, Bronislav I. - Beznosova, Tatiana M. - Matveev, Vladimir A. - Gömze, László A.: Environment changes at the Ludlow and Pridoli boundary (Subpolar Urals)

Építőanyag - Journal of Silicate Based and Composite Materials, Vol. 69, No. 3 (2017), 132-134. p.

https://doi.org/10.14382/epitoanyag-jsbcm.2017.24

Környezetváltozás a Ludlowi és Pridoli korok határán (sarkvidéki Ural)

A szerzôk által vizsgált és jelen munkában bemutatott Felsố-Silurian szakasz az Urál-hegység sarkköri (Subpoláris) részének nyugati lejtôjén található, a Kozhim folyó partján. Ez a tanulmány bemutatja a Ludlow felsố szakasz geológiai felépítésének szerkezetét, valamint vizsgálati adatokat a késố Ludlow illetve a Ludlow és a Pridoli határában található szárazföldi karbonát lelôhelyek litológiájára, geokémiájára és környezeti rekonstrukciójára vonatkozóan. 